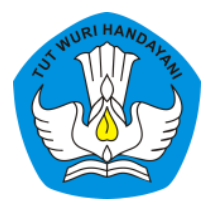

Page: 225-240

\title{
BINGKAI PECAHAN BERBASIS MIKIR UNTUK MENINGKATKAN AKTIVITAS BELAJAR DAN PEMAHAMAN KONSEP PENJUMLAHAN PECAHAN DI SEKOLAH DASAR
}

\author{
Budiyanto \\ Sekolah Dasar Negeri Padike II, Sumenep, Jawa Timur, Indonesia \\ Contributor Email: budint845@gmail.com
}

Received: Jan 26, 2021

Accepted: Mar 10, 2021

Published: Mar 30, 2021

Article Url: https://ojsdikdas.kemdikbud.go.id/index.php/didaktika/article/view/219

\begin{abstract}
The understanding of the concept of adding fractions of grade V SD Negeri Padike II students is low and has not reached the KKM (Minimum Completeness Criteria) that has been set by the school. It can be seen from the number of students as many as 23 people, who have fulfilled the KKM as many as 8 people $(34.78 \%)$, while 15 people $(65.22 \%)$ do not meet. This is because during learning, students are not actively involved, starting from experiencing, interacting, communicating, being inspired, and reflecting. So that props are needed that can help them so that they active in learning process and improve the understanding of the concept of adding fractions. The purpose of this study was to describe the increase in learning activities and understanding of the concept of adding fractions to fifth grade students of SD Negeri Padike II, Sumenep Regency. This research method uses classroom action research methods that aim to improve the quality of learning by describing learning activities and understanding the concept of adding fractions for students through quantitative and qualitative data. The results obtained after applying the MIKIR (Mengalami, Interaksi, Komunikasi, Inspirasi, Refleksi) of students who did not complete were only $4(17 \%)$ and 19 (83\%) who completed or exceeded the KKM. It can be concluded that the MIKIR can increase learning activities and understanding the concept of adding fractions.
\end{abstract}

Keywords: Frame; MIKIR; Addition of Fractions 


\begin{abstract}
Abstrak
Pemahaman konsep penjumlahan pecahan peserta didik kelas V SD Negeri Padike II rendah dan belum mencapai KKM (Kriteria Ketuntasan Minimal) yang telah ditetapkan sekolah. Dari 23 orang peserta didik yang dapat mencapai KKM hanya 8 orang (34,78\%), sedangkan 15 orang (65,22\%) belum mampu memenuhi. Hal ini disebabkan selama pembelajaran berlangsung peserta didik tidak terlibat aktif mulai dari mengalami, berinteraksi, berkomunikasi, terinspirasi, dan refleksi. Karena itu, diperlukan alat peraga yang dapat membantu agar mereka aktif belajar dan dapat memahami konsep penjumlahan pecahan. Tujuan penelitian ini adalah untuk mendeskripsikan peningkatan aktivitas belajar dan pemahaman konsep penjumlahan pecahan pada peserta didik kelas V SD Negeri Padike II Kabupaten Sumenep dengan menggunakan Bingkai Pecahan Berbasis MIKIR (mengalami, interaksi, inspirasi, komunikasi, dan refleksi). Metode penelitian ini menggunakan metode penelitian tindakan kelas yang bertujuan memperbaiki kualitas pembelajaran dengan mendeskripsikan aktivitas belajar dan pemahaman konsep penjumlahan pecahan bagi peserta didik melalui data kuantitatif dan kualitatif. Setelah menerapkan Bingkai Pecahan Berbasis MIKIR jumlah peserta didik yang tidak tuntas tinggal 4 orang (17\%) dan 19 orang (83\%) lainnya tuntas atau melampaui KKM. Dapat disimpulkan bahwa Bingkai Pecahan Berbasis MIKIR dapat meningkatkan aktivitas belajar dan pemahaman konsep penjumlahan pecahan.
\end{abstract}

Kata Kunci: Bingkai; MIKIR; Penjumlahan Pecahan

\title{
A. Pendahuluan
}

Matematika merupakan salah satu pembelajaran wajib sekolah mulai dari sekolah dasar sampai sekolah menengah. Hal ini menunjukkan begitu pentingnya mata pelajaran tersebut, karena beberapa konsep dalam matematika tidak terlepas dalam kehidupan sehari-hari. Tidak heran jika mata pelajaran ini selalu ada dalam setiap kurikulum, baik kurikulum 2013, Kurikulum 2006, maupun kurikulum-kurikulum sebelumnya.

Menurut Soejadi (2010), materi atau bahan ajar matematika untuk tingkat sekolah dasar disebut sebagai "mathematics for all", yang berarti bahwa materi tersebut harus mendasari matematika lebih lanjut dan dapat diaplikasikan dalam kehidupan sehari-hari. Matematika merupakan salah satu pelajaran yang fungsinya dapat mengembangkan kemampuan berkomunikasi dengan menggunakan simbol-simbol dan bilangan, meningkatkan tajamnya nalar yang berfungsi memperjelas dan 


\section{Budiyanto}

menyelesaikan masalah dalam kehidupan sehari-hari. Dengan demikian dibutuhkan kemampuan guru dalam mengelola pembelajaran matematika agar peserta didik tidak jenuh, namun menjadi senang dan merasa butuh terhadap mata pelajaran yang satu ini.

Mengatasi permasalahan di atas dalam pembelajaran matematika, salah satu yang penting dilakukan oleh guru adalah memfasilitasi peserta didik agar dapat dengan mudah memahami konsep-konsep matematika. Untuk memudahkan pemahaman konsep tersebut satu di antara yang perlu dilakukan guru adalah menyediakan dan memanfaatkan alat peraga yang dapat membuat siswa mengalami langsung. Alat peraga yang digunakan tersebut tidaklah harus mahal, yang penting bermanfaat untuk memudahkan siswa dalam memahami materi pembelajaran. Bahkan, guru dapat memanfaatkan benda-benda bekas dari lingkungan sekitar.

Salah satu materi dalam matematika sekolah dasar yang dalam pembelajarannya membutuhkan penggunaan alat peraga adalah materi penjumlahan pecahan. Sebab, tidak banyak guru dalam proses pembelajaran penjumlahan pecahan menggunakan alat peraga. Guru hanya menggunakan rumus-rumus, sehingga peserta didik kesulitan dalam memahami konsep tersebut.

Terkait dengan hal di atas, penulis melakukan observasi pada kelas V SD Negeri Padike II Sumenep untuk mendapatkan informasi tentang proses dan hasil pembelajaran matematika, yakni tentang muatan konsep penjumlahan pecahan. Berdasarkan hasil observasi dan analisis tersebut, penulis menemukan tiga hal penting berikut ini. Pertama, proses pembelajaran masih cenderung searah, yakni guru lebih dominan aktif dari pada peserta didik. Pada saat pembelajaran metode ceramah lebih banyak digunakan oleh guru ditambah dengan memberikan tugas-tugas sesuai yang ada di buku, sementara peserta didik cukup dengan duduk mendengarkan penjelasan guru. Padahal dalam pembelajaran matematika seperti juga pembelajaran lainnya peserta didik harus lebih aktif daripada guru. Ini sesuai dengan pernyataan Siswono (2012) bahwa pembelajaran 
matematika menuntut peserta didik aktif mencari, merumuskan, menyelidiki, mengaplikasikan, dan membuktikan yang dipelajari sehingga ia mendapatkan pembelajaran bermakna.

Kedua, saat pembelajaran guru tidak menggunakan media atau alat peraga yang dapat membantu pemahaman konsep penjumlahan pecahan. Dampaknya, peserta didik kesulitan memahami konsep tersebut. Padahal sebagaimana diungkapkan Piaget dalam buku Psikologi Perkembangan Anak bahwa usia antara 6 sampai 11 tahun merupakan tahap operasional konkret. Mereka dapat mengurangi, menambah, dan mengubah dibantu oleh berbagai benda konkret (Dahlan: 2007). Oleh karena itu, dalam pembelajaran apapun terlebih matematika diharapkan memanfaatkan alat peraga yang dapat membuat mereka mengalami langsung melalui benda-benda konkret.

Ketiga, selama proses pembelajaran guru kurang mengajak atau menstimulasi peserta didik untuk aktif berinteraksi, berkomunikasi, menginspirasi, dan melakukan refleksi. Agar pembelajaran tidak monoton, guru harus mampu menciptakan pembelajaran yang dapat membuat peserta didik mendapatkan motivasi dan inovasi dalam pembelajaran. Pembelajaran yang monoton berdampak terhadap hasil belajar mereka, yakni nilai yang diperoleh peserta didik masih di bawah rata-rata. Peserta didik kehilangan inspirasi untuk semangat dan memahami konsep pembelajaran penjumlahan pecahan.

Peneliti juga menyebarkan angket kepada peserta didik untuk menguatkan temuan tersebut. Selain itu juga dikuatkan dengan wawancara yang tidak terstruktur ke peserta didik. Hasilnya, diperoleh data bahwa materi yang mereka anggap sulit adalah penjumlahan pecahan. Kesulitan tersebut disebabkan guru dalam membelajarkan materi tersebut tidak menggunakan alat peraga. Dengan demikian aktivitas belajar peserta didik tidak optimal dan mengakibatkan mereka tidak memahami konsep penjumlahan.

Untuk mengatasi permasalahan yang ditemukan di atas, penulis meyakini bahwa dibutuhkan alat peraga yang sesuai berupa benda-benda 


\section{Budiyanto}

sekitar yang dapat dialami langsung oleh peserta didik. Penulis mencoba merancang alat peraga berupa triplek dan kardus bekas serta mika transparan. Alat peraga ini penulis beri nama Bingkai Pecahan Berbasis MIKIR (mengalami, interaksi, komunikasi, inspirasi, dan refleksi. Dengan alat peraga ini peserta didik akan merasa senang dan menikmati pembelajaran sehingga tujuan pembelajaran dapat secara mudah dicapai.

Bingkai Pecahan Berbasis MIKIR sengaja dirancang untuk memudahkan pemahaman konsep penjumlahan pecahan. Beberapa kelebihan alat peraga Bingkai Pecahan Berbasis MIKIR adalah bahan mudah didapat dan dibuat, harga terjangkau, serta dapat membuat peserta didik mengalami langsung. Dengan peserta didik mengalami langsung pemanfaatan alat peraga ini, mereka akan mudah mengingat kembali dan mudah memahami konsep penjumlahan pecahan tersebut.

Alat peraga ini juga dapat memudahkan peserta didik untuk berinteraksi dan berkomunikasi. Termasuk di dalamnya membuat peserta didik mudah melakukan refleksi pembelajaran. Dengan menggunakan alat peraga ini peserta didik akan termotivasi untuk meningkatkan aktivitas belajar dan pemahaman konsep penjumlahan pecahannya.

Penelitian ini bertujuan untuk (1) mendeskripsikan peningkatan aktivitas belajar peserta didik kelas V SD Negeri Padike II Kabupaten Sumenep dalam pembelajaran penjumlahan pecahan alat peraga Bingkai Pecahan Berbasis MIKIR, dan (2) mendeskripsikan peningkatan pemahaman konsep penjumlahan pecahan bagi peserta didik kelas V SD Negeri Padike II Kabupaten Sumenep setelah menggunakan Bingkai Pecahan Berbasis MIKIR.

\section{B. Metode}

Subjek penelitian ini yakni peserta didik kelas V SD Negeri Padike II Kabupaten Sumenep. Jumlah peserta didik kelas V sebanyak 23 orang, yang terdiri atas 11 orang laki-laki dan 12 orang perempuan. Alasan memilih kelas $\mathrm{V}$ sebagai subjek penelitian karena berdasarkan hasil 
observasi dan wawancara kepada guru-guru didapatkan hasil belajar peserta didik pada mata pelajaran matematika materi utamanya penjumlahan pecahan masih banyak peserta didik belum memenuhi KKM yang telah ditentukan.

Penelitian ini menggunakan rancangan penelitian tindakan kelas karena penelitian ini dilakukan untuk menyelesaikan permasalahan pembelajaran di kelas. Permasalahan yang dimaksud ialah rendahnya aktivitas belajar peserta didik dan pemahaman konsep penjumlahannya. Dengan demikian kehadiran peneliti di sekolah mutlak dan sangat menentukan. Kehadiran peneliti sebagai instrumen kunci dan pemberi tindakan dalam penelitian. Penelitian ini dilakukan secara kolaboratif dengan guru dalam melaksanakan perencanaan, merancang rencana pelaksanaan pembelajaran dan menyiapkan perlengkapan pembelajaran. Dalam pelaksanaan tindakan, guru berperan sebagai pengamat, sedangkan peneliti berperan sebagai guru.

Penelitian ini dilaksanakan pada bulan Februari-Maret 2019. Pelaksanaan pengamatan dibantu oleh 1 orang observer dan peneliti berkolaborasi dengan guru kelas. Kehadiran peneliti dalam hal ini berperan sebagai pemberi tindakan itu mengajar sesuai jadwal yang telah ditentukan, pembuat Rencana Pelaksanaan Pembelajaran (RPP) selama berlangsungnya kegiatan penelitian, pengumpul data terhadap subjek penelitian. Peneliti juga bertindak sebagai sebagai perancang, penyumbang ide, dan pemeran utama dalam pelaksanaan kegiatan penelitian. Bingkai Pecahan Berbasis MIKIR (mengalami, interaksi, komunikasi, inspirasi, dan refleksi) secara konseptual dikerangkakan sebagai berikut. 


\section{Budiyanto}

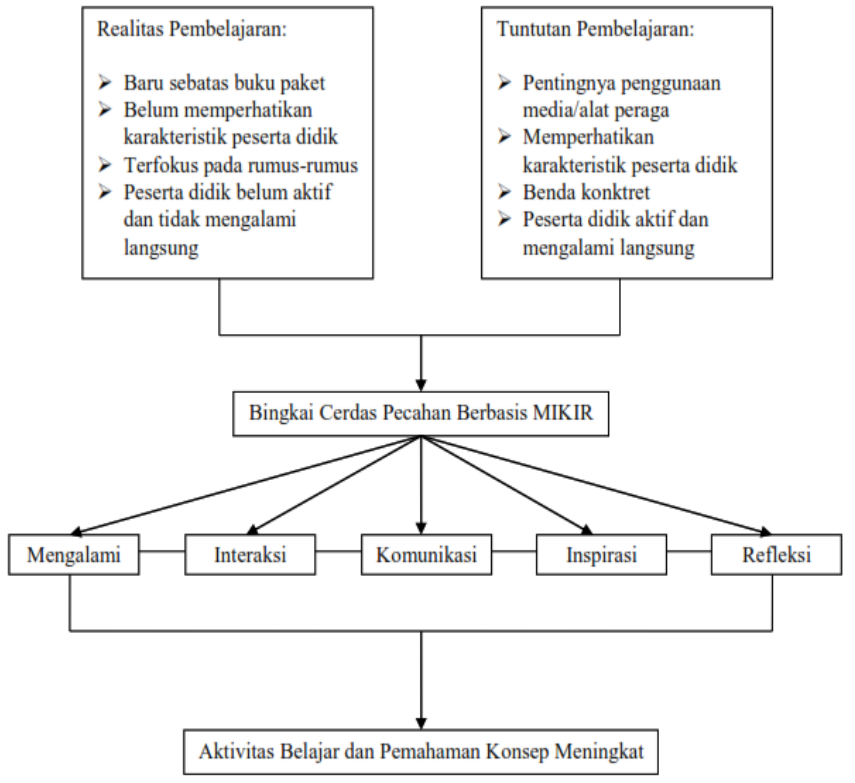

Gambar 1: Kerangka Konseptual

\section{Hasil dan Pembahasan}

\section{Hasil}

Sebelum dilakukan tindakan, hasil belajar peserta didik pada mata pelajaran Matematika khususnya penjumlahan pecahan sangat rendah dan belum mencapai KKM yang telah ditetapkan sekolah. Hal ini sebagaimana terlihat pada table di bawah ini.

Table 1

Hasil Belajar Peserta Didik Sebelum Tindakan

\begin{tabular}{ccccc}
\hline No & Rentang Nilai & Frekuensi & Persentase & Keterangan \\
\hline 1 & $75-100$ & 8 & 34,78 & Tuntas \\
2 & $0-74$ & 15 & 65,22 & Belum Tuntas \\
\hline
\end{tabular}

Berdasarkan tabel di atas diketahui bahwa dari 23 orang siswa kelas V, yang sudah memenuhi Kriteria Ketuntasan Minimal (KKM) hanya8 orang $(34,78 \%)$, sedangkan 15 orang $(65,22 \%)$ peserta didik masih 
belum memenuhi Kriteria Ketuntasan Minimal. Dengan demikian, baik secara individu maupun secara klasikal ketuntasan belajar belum dapat dicapai sesuai dengan ketentuan sekolah, sebagaimana terdapat pada grafik 1 dibawah ini.

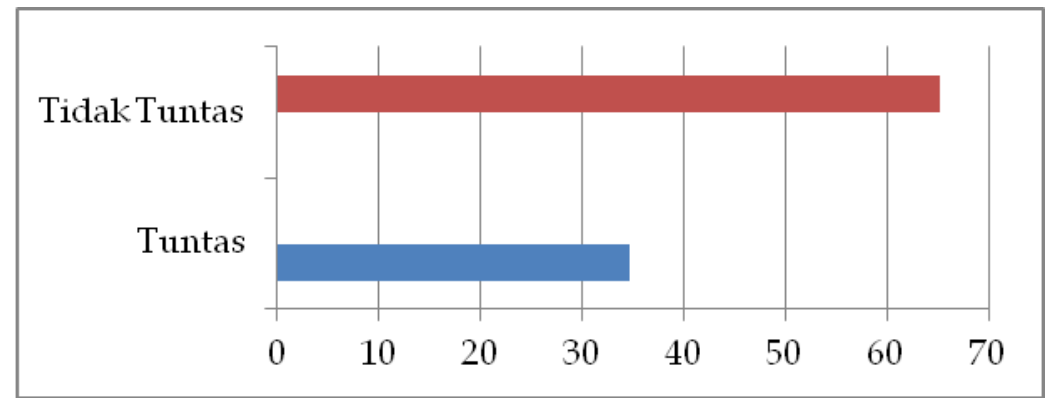

Grafik 1. Nilai Studi Awal Sebelum Siklus I

\section{a. Paparan Data Siklus 1}

Dalam pertemuan siklus I ini tindakan yang dilakukan meliputi: (1) perencanaan tindakan, (2) pelaksanaan tindakan, (3) observasi, dan (4) refleksi. Tindakan siklus I dilakukan selama 3 pertemuan dengan alokasi waktu 3x35 menit. Pelaksanaan tindakan siklus I ini dilaksanakan selama tiga hari efektif pembelajaran.

Keterlaksanaan pembelajaran diukur dengan menggunakan lembar observasi aktivitas guru dalam pelaksanaan pembelajaran. Instrumen ini diisi oleh observer. Hasil data tersebut digunakan sebagai perbaikan pembelajaran selanjutnya. Hasil observasi aktivitas guru dalam pembelajaran dapat dilihat pada tabel berikut ini.

\section{Tabel 2}

Rekapitulasi Observasi Aktivitas Guru dalam Pembelajaran

\begin{tabular}{clcccc}
\hline \multirow{2}{*}{ No } & \multirow{2}{*}{ Rekapitulasi } & \multicolumn{3}{c}{ Pertemuan } & \multirow{2}{*}{ Rata-rata } \\
\cline { 3 - 5 } & & 1 & 2 & 3 & \\
\hline 1 & Jumlah Skor & 23 & 28 & 31 & 27 \\
2 & Presentase Nilai Rata-Rata & $54 \%$ & $66 \%$ & $73 \%$ & $64 \%$ \\
3 & Taraf Keberhasilan & Cukup & Baik & Baik & Baik \\
\hline
\end{tabular}


Berdasarkan data hasil pembelajaran yang dilakukan guru selama pelaksanaan siklus I sudah sesuai dengan Rencana Pelaksanaan Pembelajaran yang disusun sebelumnya. Persentase nilai rata-rata yang didapat guru dalam pembelajaran adalah $64 \%$ dengan taraf keberhasilan kategori baik. Kekurangan terdapat pada peserta didik karena belum memahami dalam mengoperasikan Bingkai Pecahan Berbasis MIKIR (mengalami, interaksi, komunikasi, inspirasi, dan refleksi). Akibatnya, alokasi waktu yang diberikan dalam pembelajaran tidak berjalan secara optimal. Hasil belajar peserta didik tentang pemahaman konsep penjumlahan pecahan setelah dilaksanakan siklus I mengalami peningkatan. Nilai atau hasil belajar siswa berdasarkan evaluasi siklus I dapat dilihat pada tabel berikut.

\section{Tabel 3}

Hasil Belajar Siklus I

\begin{tabular}{clccc}
\hline No & Rentang Nilai & Frekuensi & Presentase & Keterangan \\
\hline 1 & $75-100$ & 10 & 43,48 & Tuntas \\
2 & $0-74$ & 13 & 56,52 & Belum Tuntas \\
\hline
\end{tabular}

Dari data tersebut dapat disimpulkan bahwa penguasaan materi sudah meningkat akan tetapi belum optimal karena ada beberapa peserta didik yang belum tuntas dalam pembelajaran atau belum mencapai kriteria ketuntasan minimal.

\section{Grafik 1.}

Nilai Tes Siklus I

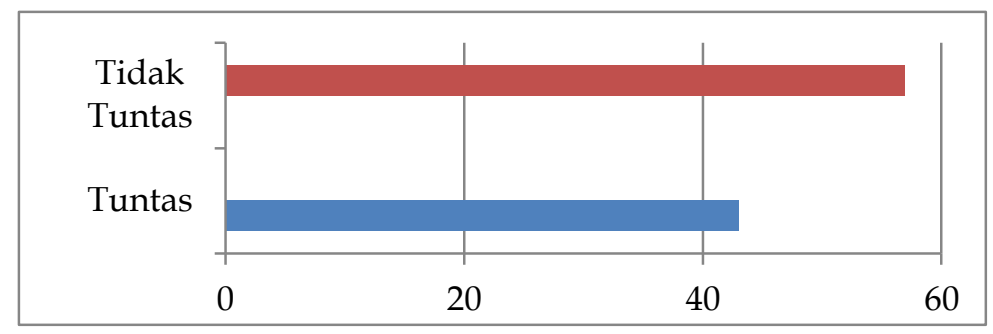

Berdasarkan hasil belajar peserta didik pada siklus I terjadi peningkatan dibandingkan pada awal pembelajaran sebelum dilakukan 
siklus I. Hal ini terjadi karena ada perubahan pembelajaran yang dilakukan oleh peneliti sehingga peserta didik aktif dalam pembelajaran.

\section{b. Paparan Data Siklus 2}

Kegiatan yang dilakukan dalam tindakan siklus II meliputi (1) perencanaan tindakan, (2) pelaksanaan tindakan, (3) observasi, dan (4) refleksi. Berdasarkan hasil diskusi dengan observer maka pelaksanaan tindakan siklus II dilaksanakan selama 2 (dua) pertemuan dengan alokasi waktu 3x35 menit. Pelaksanaan tindakan siklus II dilaksanakan pada tiga hari efektif pembelajaran.

Keterlaksanaan pembelajaran dalam penjumlahan pecahan pada peserta didik kelas V SD Negeri Padike II Kabupaten Sumenep diukur dengan menggunakan lembar observasi aktivitas guru dalam pelaksanaan pembelajaran. Instrumen ini diisi oleh observer. Hasil rekapitulasi observasi aktivitas guru dalam pembelajaran dapat dilihat dalam tabel di bawah ini:

Tabel 4.

Rekapitulasi Observasi Aktivitas Guru dalam Pembelajaran

\begin{tabular}{clccc}
\hline \multirow{2}{*}{ No } & \multirow{2}{*}{ Rekapitulasi } & \multicolumn{2}{c}{ Pertemuan } & \multirow{2}{*}{ Rata-rata } \\
\cline { 3 - 4 } & & 1 & 2 & \\
\hline 1 & Jumlah Skor & 30 & 36 & 33 \\
2 & Presentase Nilai Rata-Rata & $71 \%$ & $85 \%$ & $78 \%$ \\
3 & Taraf Keberhasilan & Cukup & Sangat Baik & Baik \\
\hline
\end{tabular}

Hasil pembelajaran yang dilakukan guru selama pelaksanaan siklus II sudah sesuai dengan Rencana Pelaksanaan Pembelajaran yang disusun sebelumnya. Persentase nilai rata-rata yang didapat guru dalam pembelajaran adalah $78 \%$ dengan taraf keberhasilan kategori baik. Kekurangan terdapat pada alokasi waktu yang diberikan dalam pembelajaran tidak terlaksana secara maksimal.

Hasil observasi aktivitas peserta didik dalam pembelajaran penjumlahan pecahan dengan menggunakan Bingkai Cerdas Berbasis 
MIKIR di siklus II berdasarkan pengamatan aktivitas peserta didik dalam mengeluarkan pendapat, menanggapi, berdiskusi/berkelompok, dan mengoperasikan Bingkai Cerdas Berbasis MIKIR. Observasi aktivitas dilakukan pada pembelajaran berlangsung. Hal ini terlihat pada indikator-indikator yang telah dibuat untuk memungkinkan yang dilakukan peserta didik dalam pembelajaran berlangsung. Hasil aktivitas belajar peserta didik pada indikator siklus II adalah 3280. Hasil observasi aktivitas tersebut dapat direkap pada aktivitas belajar peserta didik dibawah ini.

Tabel 5

Rekapitulasi Observasi Aktivitas Belajar Peserta Didik

\begin{tabular}{|c|c|c|c|c|}
\hline No & Pertemuan & Skor Total & Rata-Rata & Kategori \\
\hline 1 & Pertama & 1580 & 79 & Aktif \\
\hline \multirow[t]{3}{*}{2} & Kedua & 1700 & 85 & Sangat Aktif \\
\hline & Jumlah & 3280 & 164 & \\
\hline & Rata-Rata & 1640 & 82 & Sangat Aktif \\
\hline
\end{tabular}

Mengacu pada tabel hasil observasi aktivitas belajar tersebut diperoleh informasi bahwa rata-rata aktivitas belajar peserta didik $82 \%$ dan masuk pada kategori sangat aktif. Hasil belajar peserta didik tentang penjumlahan pecahan setelah dilaksanakan siklus II mengalami peningkatan. Hasil nilai evaluasi Siklus II seperti terlihat pada tabel berikut.

Tabel 6

Pemahaman Konsep Penjumlahan Pecahan Peserta Didik

\begin{tabular}{ccccc}
\hline No & Rentang Nilai & Frekuensi & Presentase & Keterangan \\
\hline 1 & $75-100$ & 19 & 82,61 & Tuntas \\
2 & $0-74$ & 4 & 17,4 & Belum Tuntas \\
\hline
\end{tabular}

Berdasarkan data tersebut dapat disimpulkan bahwa penguasaan pemahaman konsep penjumlahan pecahan meningkat akan tetapi belum 
optimal karena ada beberapa peserta didik yang belum tuntas dalam pembelajaran atau belum mencapai kriteria ketuntasan minimal.

\section{Grafik 2: Ketuntatasan Minimal}

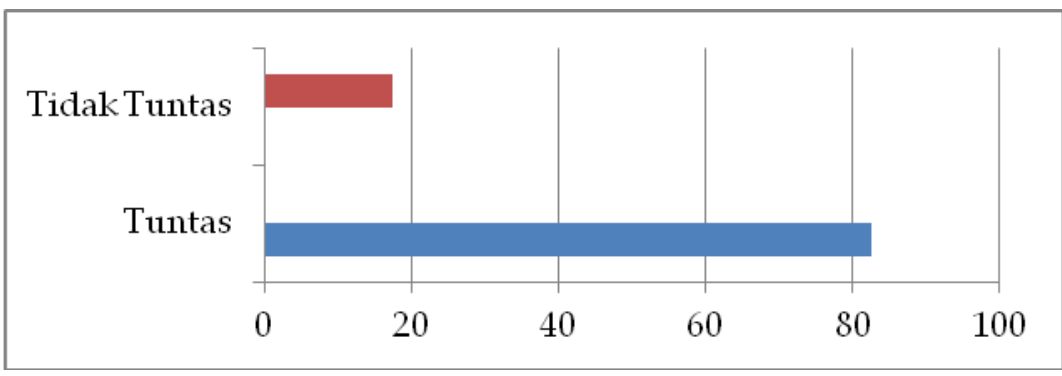

Berdasarkan penilaian belajar peserta didik tentang pemahaman konsep penjumlahan pada siklus II dapat diketahui telah terjadi peningkatan dibandingkan pada awal pembelajaran sebelum dilakukan siklus II. Hal ini terjadi karena ada perubahan pembelajaran yang dilakukan oleh guru sehingga peserta didik dapat mengalami, berinteraksi, berkomunikasi, terinspirasi, dan merefleksi selama pembelajaran.

\section{Pembahasan}

Hasil penelitian menunjukkan aktivitas dan pemahaman konsep penjumlahan pecahan peserta didik mengalami peningkatan. Peningkatan aktivitas dan pemahaman konsep tersebut terjadi karena penerapan Bingkai Cerdas Pecahan Berbasis MIKIR (mengalami, interaksi, komunikasi, inspirasi, dan refleksi). Hal ini dilihat dengan meningkatnya aktivitas dan pemahaman konsep penjumlahan pecahan peserta didik pada setiap siklus yang dilakukan.

Hasil belajar peserta didik terendah pada awal sebelum tindakan adalah 45, sedangkan nilai tertinggi 85; dengan nilai rata-rata sebesar $66,91 \%$. Dalam melakukan perbaikan pembelajaran pada setiap siklus yang dilakukan guru perlu menyusun skenario pembelajaran yang tepat untuk dilaksanakan pada setiap siklus. Pada siklus I hasil yang diperoleh belum optimal, maka guru melakukan perbaikan pembelajaran pada 


\section{Budiyanto}

siklus II. Hasil belajar peserta didik mengalami peningkatan pada akhir tindakan pembelajaran siklus I dengan nilai rata-rata sebesar 70. Pada akhir siklus II peningkatan pembelajaran sangat baik dengan nilai ratarata yang didapat sebesar 78 , artinya peningkatan pembelajaran secara signifikan terjadi pada siklus II.

a. Peningkatan Aktivitas Belajar Setelah Penerapan Bingkai Pecahan Berbasis MIKIR (mengalami, interaksi, komunikasi, inspirasi, dan refleksi)

Setelah Penerapan Bingkai Cerdas Pecahan Berbasis MIKIR (mengalami, interaksi, komunikasi, inspirasi, dan refleksi) pada proses pembelajaran telah terlihat keaktifan peserta didik. Pembelajaran tidak hanya terfokus pada guru, namun peserta didik terlihat antusias dan termotivasi selama proses pembelajaran. Selama proses pembelajaran peserta didik mengalami langsung, berinteraksi, berkomunikasi, terinspirasi, dan dapat melakukan refleksi.

Berdasarkan pengamatan dapat disimpulkan bahwa setelah penerapan Bingkai Cerdas Pecahan Berbasis MIKIR (mengalami, interaksi, komunikasi, inspirasi, dan refleksi) dapat meningkatkan aktivitas belajar peserta didik selama proses pembelajaran. Hal ini tentu berdampak pada pemahaman konsep penjumlahan pecahan peserta didik.

\section{b. Peningkatan Pemahaman Konsep Penjumlahan Pecahan setelah Penerapan Bingkai Pecahan Berbasis MIKIR (mengalami, interaksi, komunikasi, inspirasi, dan refleksi)}

Pemahaman konsep penjumlahan pecahan peserta didik setelah diterapkan Bingkai Cerdas Pecahan Berbasis MIKIR (mengalami, interaksi, komunikasi, inspirasi, dan refleksi) sangat bagus dan menunjukkan adanya peningkatan yang signifikan. Berdasarkan data tersebut dapat disimpulkan bahwa pemahaman konsep penjumlahan pecahan sudah meningkat meskipun masih ada beberapa peserta didik yang belum tuntas dalam pembelajaran atau belum mencapai kriteria ketuntasan minimal. Namun jika dibandingkan dengan sebelum 
diterapkan Bingkai Cerdas Berbasis MIKIR (mengalami, interaksi, komunikasi, inspirasi, dan refleksi) ditambah dengan KKM yang telah ditetapkan sekolah, dapat dinyatakan berhasil.

Dengan menggunakan Bingkai Pecahan Berbasis MIKIR maka dalam proses pembelajarannya membuat peserta didik dapat mengalami, berinteraksi, berkomunikasi, terinspirasi, dan melakukan refleksi. Kegiatan mengalami misalnya, selama proses pembelajaran peserta didik dapat memegang, memasukkan batang pecahan, kemudian menghitungnya. Dengan begitu peserta didik akan terlibat langsung. Hal ini akan lebih mudah diingatnya karena melakukan sendiri itu lebih baik dari hanya mendengarkan atau melihat.

Kegiatan interaksi misalnya, saat proses pembelajaran penjumlahan pecahan berlangsung peserta didik akan termotivasi untuk memberikan pertanyaan atau tanggapannya baik kepada guru maupun kepada peserta didik lainnya. Termasuk juga pada kegiatan komunikasi, melalui alat peraga Bingkai Pecahan Berbasis MIKIR. Setelah peserta didik mengalami dan berinteraksi, mereka selanjutnya didorong untuk mengomunikasikan hasil kegiatannya.

Setelah peserta didik melakukan kegiatan yang meliputi mengalami, interaksi, dan komunikasi, maka guru bersama peserta didik akan terinspirasi untuk meningkatkan aktivitas belajarnya. Terakhir, dari proses tersebut adalah guru bersama peserta didik melakukan refleksi pembelajaran. Ketika berbagai aktivitas belajar ini terus dilaksanakan baik oleh guru maupun peserta didiknya, maka pembelajaran akan menyenangkan yang pada akhirnya dapat meningkatkan hasil belajar mereka.

\section{Penutup}

Berdasarkan hasil penerapan Bingkai Pecahan berbasis MIKIR (mengalami, interaksi, komunikasi, inspirasi, dan refleksi) dapat disimpulkan bahwa Bingkai Pecahan Berbasis MIKIR (dapat 
meningkatkan aktivitas belajar peserta didik SD Negeri Padike II Kabupaten Sumenep dalam pembelajaran penjumlahan pecahan. Bingkai Pecahan Berbasis MIKIR (mengalami, interaksi, komunikasi, inspirasi, dan refleksi) juga dapat meningkatkan pemahaman konsep penjumlahan pecahan secara signifikan pada peserta didik kelas V SD Negeri Padike II Kabupaten Sumenep.

Berdasarkan hasil penelitian tersebut dapat diberikan beberapa saran. Bagi guru, hendaknya terus berinovasi untuk menghasilkan karya inovasi pembelajaran, di antaranya dengan memanfaatkan benda-benda bekas sekitar seperti triplek, kardus, atau benda bekas lainnya. Harapannya, akan menghasilkan alat peraga lainnya selain Bingkai Cerdas Pecahan Berbasis MIKIR (mengalami, interaksi, komunikasi, inspirasi, dan refleksi). Dalam mengembangkan karya inovasi pembelajaran guru perlu memperhatikan kebutuhan dan karakteristik peserta didik, sehingga kompetensi semua peserta didik dapat difasilitasi oleh guru. Bagi peserta didik, mereka hendaknya dapat menggunakan Bingkai Cerdas Pecahan Berbasis MIKIR tanpa ragu bahkan lebih baik bila mereka dapat membuatnya sendiri yang menyerupai Bingkai Cerdas Pecahan Berbasis MIKIR seperti dari kardus bekas atau benda bekas lainnya. Dengan begitu, peserta didik akan termotivasi dan terinspirasi dalam belajarnya. Terakhir, kepala sekolah hendaknya memberikan dukungan penuh kepada guru dan peserta didik dalam mengembangkan karya inovasi pembelajarannya. Dengan demikian, perhatian dan kerjasama antara guru dengan kepala sekolah tetap terjalin demi tercapainya tujuan pembelajaran yang diinginkan.

\section{Ucapan Terimakasih}

Penulis mengucapkan terimakasih kepada kepala sekolah, para guru dan tenaga kependidikan, serta semua peserta didik kelas V SD Negeri Padike II Kabupaten Sumenep yang telah banyak membantu dan mendukung penelitian ini. Berkat bantuan dan dukungan dari mereka, artikel ini dapat penulis selesaikan sesuai harapan. 


\section{Daftar Referensi}

Dahlan M. Djawad. (2007). Psikologi Perkembangan Anak dan Remaja. Bandung: Remaja Rosdakarya.

Depdiknas. (2009). Kurikulum Tingkat Satuan Pendidikan. Jakarta: Pusat Kurikulum, Balitbang Depdiknas.

Fazriyah, N. (2016). Kemampuan Berpikir Kritis pada Pembelajaran Abad 21 di Sekolah Dasar. Prosiding Seminar Nasional Pendidikan Dasar Pengembangan Kemampuan Berpikir Kritis, Kreativitas, Komunikasi dan Kolaborasi Dalam Pembelajaran Abad 21: Inovasi Pembelajaran Abad 21, 1 (Desember 2016), 978-979.

Hosnan. (2014). Pendekatan Saintifik dan Kontekstual dalam Pembelajaran Abad 21 Kunci Sukses Implementasi Kurikulum 2013. Bogor: Ghalia Indonesia.

Ismiati. (2013). Penggunaan Blok Pecahan untuk Meningkatkan Kemampuan Bilangan Pecahan Sederhana.

Komariah. (2013). Penggunaan Kartu Bilangan untuk Meningkatkan Hasil Belajar Penjumlahan dan Pengurangan Bilangan Pecahan pada Mata Pelajaran Matematika kelas V SD Al-Amin Surabaya.

Sardiman. (2012). Interaksi dan Motivasi Belajar Mengajar. Jakarta: Raja Grafindo Persada.

Siswono. (2012). Pembelajaran Matematika SD. Bandung: Remaja Rosdakarya.

Soedjadi. (2000). Kiat Pendidikan Matematika di Indonesia Konstatasi Keadaan Masa Kini Menuju Harapan Masa Depan. Jakarta: Dikti. 